\title{
RESEARCH
}

\section{Bacterial Artificial Chromosome Cloning and Mapping of a 630-kb Human Extrachromosomal Structure}

\author{
Min Wang, ${ }^{1}$ Stephanie Shouse, ${ }^{1}$ Barbara Lipes, ${ }^{1}$ Ung-Jin Kim, ${ }^{2}$ \\ Hiroaki Shizuya, ${ }^{2}$ and Eric Lai ${ }^{1,3}$
}

${ }^{1}$ Department of Pharmacology, University of North Carolina at Chapel Hill, Chapel Hill, North Carolina
27599-7365; ${ }^{2}$ Division of Biology, California Institute of Technology, Pasadena, California 91125

We have cloned and mapped a circular 630-kb human extrachromosomal structure (termed amplisome) using the bacterial artificial chromosome (BAC) cloning system. Twenty-one BACs were isolated from an amplisome-enriched library by colony hybridization. The insert sizes range from 25 to $143 \mathrm{~kb}$, with an average size of $82 \mathrm{~kb}$. The coverage of the amplisome in clones is $\sim 2.7$-fold. To construct a physical map of the amplisome, we used three different but complementary methods: hybridization, STS content mapping, and fingerprinting. In addition, we compared the advantages and the drawbacks of these techniques in mapping the amplisomal BACs. The 21 BACs were grouped into two contigs and the two small gaps ( 3.5 and $26.5 \mathrm{~kb}$ ) were filled by screening of a human genomic BAC library. The organization of the amplisome revealed by the BAC-based physical map is consistent with the long-range restriction map reported previously. Our results demonstrate that a $630-\mathrm{kb}$ region can be rapidly cloned and mapped into contigs by use of the BAC system. Because of the low frequency $(<0.1 \%)$ of chimerism and rearrangement, these BAC clones are ready for DNA sequencing and functional analysis.

Human cell line HeLa-Bu25-10B3 was isolated by selection for growth in stepwise increases in methotrexate (MTX) concentration, and although it contains 300 copies of the dihydrofolate reductase (DHFR) gene, it lacks homogeneously staining regions (HSRs) and contains few (0-3 per cell) double minutes (DMs) (Masters et al. 1982). Further studies have shown that the DHFR gene is located on a $630-\mathrm{kb}$ extrachromosomal element, termed an amplisome (Maurer et al. 1987). It has been found that the amplisome does not change in size and copy number during long-term culture with MTX selection, and its loss is much slower than that expected from simple dilution upon withdrawal of MTX (Pauletti et al. 1990). The amplisome was found to have one copy of the DHFR gene per molecule, and no repetitive structure was observed (Esnault et al. 1994). To characterize further the structure and organization of the DNA sequences on am-

${ }^{3}$ Corresponding author. Present address: GlaxoWellcome, Inc., Research Triangle Park, North Carolina 27709.

E-MAIL. ehl21 107@glaxo.com; FAX (919) 483-0315. plisomes, we have cloned amplisomal DNA in a large insert vector system.

Recently, bacterial vectors based on the bacteriophage P1 (Sternberg 1990) and on the Escherichia coli fertility plasmid [F-factor; bacterial artificial chromosomes (BAC)] (O'Conner et al. 1989; Hosoda et al. 1990; Shizuya et al. 1992) have been developed for the cloning of large DNA. These systems have a very low frequency of chimerism, and the inserts are very stable during propagation (Shizuya et al. 1992). BACs utilize the well-studied E. coli single-copy fertility plasmid and have been shown to be able to accept human DNA inserts as large as $300 \mathrm{~kb}$. Very little or no rearrangement of the inserts has been observed even after $>100$ generations of serial growth (Shizuya et al. 1992). The transformation efficiency of the BAC can be as high as $10^{7}$ clones/ $\mu \mathrm{g}$ of DNA (Wang et al. 1994). Because of these advantages, we have used the BAC vector to construct an amplisome library and a physical map with hybridization, STS mapping, and fingerprinting. Our results demonstrate the efficiency and feasibility of the BAC cloning system 


\section{GENOMIC CLONING IN BACS}

in genomic mapping. Finally, we have compared the structure and organization of the amplisomal DNA sequences to that of double minute chromosomes and homogeneous staining regions.

\section{RESULTS}

\section{Cloning of the Amplisome DNA into Cosmid and YAC Vectors}

The 630-kb amplisome in HeLa-Bu25-10B3 cells contains a single NotI site permitting isolation of the complete sequence following NotI digestion and preparative pulsed-field gel electrophoresis (PGFE). This 630-kb linear fragment was ligated with NotI-digested pYAC4 vector and transformed into the yeast host AB1380 (Burke et al. 1987). More than half of the recombinant clones $(\sim 50)$ obtained were positive for hybridization with a DHFR cDNA probe (pHD84; Maurer et al. 1987) by hybridization. After streaking and rehybridizing colonies that had originally been positive for DHFR hybridization, however, it was found that a large proportion of these clones lost their ability to hybridize the DHFR cDNA. PFGE analysis revealed that the size of the YACs in these clones decreased progressively with continuous culturing on plates (data not shown). We failed in numerous attempts (more than three) to isolate a YAC clone with an insert size $>600 \mathrm{~kb}$. In an attempt to construct a physical map of this structure, the NotI $630-\mathrm{kb}$ fragment was also partially digested with Sau3A and cloned into the BamHI site of the cosmid vector pWE15. About 1000 clones were picked and screened by hybridization with the DHFR cDNA clone pHD84 and gel-purified amplisomal DNA blocked with total placental human DNA. One hundred twenty amplisomal cosmid clones were identified by this approach. However, we were not able to group these cosmids into contigs by either fingerprinting or hybridization experiments. Mapping of the cosmid clones onto the long-range restriction map and later onto the BAC-based physical map indicated that most of the cosmid clones were rearranged (data not shown; see Discussion).

\section{Amplisomal BAC Library Construction}

Twenty-one BAC clones containing amplisomal DNA were obtained as described in Methods. Of the 21 clones identified by hybridization to the amplisome, 5 were positive for the human DHFR cDNA probe. PFGE analysis of these amplisomal $\mathrm{BAC}$ clones has shown that the inserts range be- tween 25 and $143 \mathrm{~kb}$, with an average size of 82 $\mathrm{kb}$ (Fig. 1 in Wang and Lai 1995). The coverage of this library is $\sim 2.7$-fold $(82 \mathrm{~kb} \times 21$ clones $=1722$ $\mathrm{kb} ; 1722 \mathrm{~kb} / 630 \mathrm{~kb}=2.73$ ). Restriction digestion and agarose gel analysis of the rest of the white colonies revealed that these clones contained only vector sequence and no human DNA insert. This is presumably caused by exonuclease activity in the BamHI restriction enzyme digestion procedure. We have consistently observed very high background of white colonies containing no insert when BamHI was used as the cloning site. This problem is not observed when HindIII was used as the cloning site in our human chromosome-specific libraries (chromosomes 1 and 2; Wang et al. 1994).

\section{Grouping of the BAC Clones by Hybridization}

We first used hybridization to analyze the relationship among the amplisomal BACs. BACs and cosmid clones containing amplisomal DNA were spotted on nylon membranes, and the membranes were hybridized with individual $\mathrm{BAC}$ and cosmid inserts as probes (data not shown). The amplisomal BAC clones can be quickly grouped in bins by this method. The five DHFR-positive clones (F5, G6, H12, I9, and I4) were chosen as the starting point to initiate walks to create contigs. In each round of walking, the entire cloned insert was used as a probe (with suppression of repetitive sequences), and with the sizes of all inserts having been determined previously, the largest clone could be used to continue the walk. Previous restriction enzyme analysis had shown that G6 and H12 contain a single NotI site that was mapped to $5^{\prime}$ of the DHFR locus (Esnault et al. 1994), whereas F5, I9, and I4 mapped to the $3^{\prime}$ direction from the DHFR locus. H12 and 19 were chosen as the next $5^{\prime}$ and $3^{\prime}$ hybridization probes, respectively, because of their large inserts (>129 kb). Hybridization with H12 detected A12 as the overlapping 5 ' clone. Hybridization with 19 detected clones C12, D8, F2, and G1 being farther in the 3 ' direction. G1 was chosen as the next walking probe, which in turn detected D4. Clones A12 and D4 did not detect any additional clones and, thus, were considered to be at the end of this contig. We then attempted to group the remaining amplisomal BAC clones. A3 was chosen as the seed clone because it contains the largest insert of $130 \mathrm{~kb}$. A3 hybridized with A5, B1, F3, I2, I10, B6, E8, and F3B at different intensities. Additional hybridization experiments revealed 


\section{WANG ET AL.}

that E8 and B6 were at the ends of this contig. Thus, hybridization experiments suggested that our coverage of the $630-\mathrm{kb}$ amplisome resulted in two contigs, of $\sim 400$ and $\sim 200 \mathrm{~kb}$. Because the coverage of the amplisomal BAC library is $<3 \times$, it is not surprising to have gaps in our initial map. Contig end clones A12, B6, D4, and E8 were used to screen a $5 \times$ human genomic BAC library (Kim et al. 1996), resulting in the isolation of four additional BAC clones. Clones 692F8 and 762E11 hybridized to both A12 and E8, closing one gap, whereas clones $611 \mathrm{~A} 8$ and $1014 \mathrm{C} 11$ hybridized to both D4 and B6, closing the other. These results suggest that we have successfully cloned the amplisomal DHFR locus by use of BACs (data summarized in Fig. 2).

\section{STS Content Mapping}

We have shown previously that both ends of BAC inserts can be sequenced directly by use of vectorspecific primers (Wang et al. 1994). This approach provides a quick and easy means of generating paired STS and walking probes. In addition, because the size of the inserts can be determined by PFGE, the exact distances between the STSs are known. We directly sequenced insert ends from 10 amplisomal BACs. Of the 20 insert ends, 19 yielded DNA sequences suitable for STS selection. One of the insert ends did not provide any readable sequences even after numerous attempts.

The 19 sequences from the $\mathrm{BAC}$ insert ends were checked against GenBank by use of the program BLAST by e-mailing the sequences to the National Library of Medicine (Altshul et al. 1990). None of the sequences matched known sequences in GenBank. Seven of the insert ends contained Alu repeats, and three contained LINE repeats in their sequences. After matching with GenBank, the insert end sequences were analyzed by the oligonucleotide/STS selection program PRIMER. Sequences from the insert ends of six clones (A5, A12, B6, D4, H12, I9) were chosen for generating STSs for confirmation of the hybridization data. These clones were chosen because of their position in the physical map and because the average distance of these STSs should be $\sim 100 \mathrm{~kb}$. STS primers were successfully selected from these sequences, and all but one (i.e., the T7 end of I9) gave a single band of the expected size when tested with human genomic DNA. The DNA sequences of the STSs are shown in Table 1 and have been deposited in dbSTS. The STS content map of the BAC clones agrees completely with the hybridization data (see Fig. 2, below, for the location of the STSs).

\section{Fingerprint Mapping of the Amplisomal BACs}

Restriction enzyme fingerprinting experiments were performed on the amplisome BACs after hybridization experiments and STS content mapping to measure the amount of overlap among clones. Fingerprinting has been developed for cosmid mapping (Branscomb et al. 1990; Lamerdin and Carrano 1993) and has been successfully applied to BAC and P1-derived artificial chromosome (PAC) (Ioannou et al. 1994) for closure of
Table 1. Sequence of the Amplisome STS

\begin{tabular}{|c|c|c|c|}
\hline BAC & $\begin{array}{l}\text { Insert } \\
\text { end }\end{array}$ & Sequences & $\begin{array}{l}\text { Size of PCR } \\
\text { product }\end{array}$ \\
\hline $\mathrm{A} 12$ & $\begin{array}{l}\text { T7F } \\
T 7 R\end{array}$ & $\begin{array}{l}\text { ACA ANG TAT ACA TGT TC TGGG } \\
\text { TCT GAA AAA TA GCC AGC TC }\end{array}$ & 150 \\
\hline $\mathrm{A} 12$ & $\begin{array}{l}\text { SPGF } \\
\text { SPGR }\end{array}$ & $\begin{array}{l}\text { TC ACT TCC ATT TCC AGT TC } \\
\text { AAA TCN TC CT IT GGC C }\end{array}$ & 273 \\
\hline B6 & $\begin{array}{l}\mathrm{TPF} \\
\mathrm{TPR}\end{array}$ & $\begin{array}{l}\text { AAA AAA TCG GAN GAC TCA TC } \\
\text { TGG ACT CTA NTT CAC CAA TC }\end{array}$ & 126 \\
\hline B6 & $\begin{array}{l}\text { SPGF } \\
\text { SPGR }\end{array}$ & $\begin{array}{l}\text { NGC ATA AGC CAT ATC ACT CT } \\
\text { AGC AGT GTC ATA TIT ACC AT }\end{array}$ & 126 \\
\hline D4 & $\begin{array}{l}\text { SPGF } \\
\text { SPGR }\end{array}$ & $\begin{array}{l}\text { ACT AAN ACT AGG GAG GIT GG } \\
\text { AAG AGG NAA CGG AAA ATA GT }\end{array}$ & 325 \\
\hline D4 & $\begin{array}{l}T 7 F \\
T 7 R\end{array}$ & $\begin{array}{l}\text { CAT CAT ATA CIG CCC AGG } \pi \\
\text { TGT IG CCA AGT CTG ATG T }\end{array}$ & 208 \\
\hline E8 & $\begin{array}{l}\text { SPGF } \\
\text { SPGR }\end{array}$ & $\begin{array}{l}\text { GAG GTG TGA CAT GAA CAG } \\
\text { AGC CTC CTA ACT TC CTC C }\end{array}$ & 105 \\
\hline E8 & $\begin{array}{l}\mathrm{TPF} \\
\mathrm{T7R}\end{array}$ & $\begin{array}{l}\text { CAA CCI CCA NGT GAC TAA IG } \\
\text { AGG GGG TAC AGG AAA GTA AG }\end{array}$ & 276 \\
\hline $\mathrm{H} 12$ & $\begin{array}{l}\text { SPGF } \\
\text { SPGR }\end{array}$ & $\begin{array}{l}\text { AGN AAG ITC GCT AGA GCC } \\
\text { CIG GGT NTC CAA ACT CCT G }\end{array}$ & 254 \\
\hline $\mathrm{H} 12$ & $\begin{array}{l}\mathrm{TTF} \\
\mathrm{TPR}\end{array}$ & $\begin{array}{l}\text { ACC TGC ATG AGG TGT CTG } \\
\text { AAT CCA CCI CIC CAG TCA G }\end{array}$ & 222 \\
\hline 19 & $\begin{array}{l}\text { SPGF } \\
\text { SPGR }\end{array}$ & $\begin{array}{l}\Pi G \text { AT TIN GCT CCT CTC C } \\
\text { ACC TGA GTG AGA } \Pi C \text { ACC TG }\end{array}$ & 187 \\
\hline
\end{tabular}


physical maps (Ashworth et al. 1995a,b). The clones were digested with EcoRI, HindIII, and BamHI to check for the amount of overlap and with rare cutting enzymes (NotI, SalI, MluI, and Sfil) to correlate the physical map with the longrange restriction map (Esnault et al. 1994). Figure 1 shows fingerprinting data resulting from $E c o$ RI digestion. The order in which the samples were loaded on the gel reflects the order of the clones indicated by the hybridization and sequencetagged site (STS)-PCR experiments. Comparison of the fingerprint and hybridization data indicated that the extent of overlap estimated by fingerprinting directly correlates with the intensity of the hybridization signal among the clones.

The fingerprint data allowed us to estimate the size of the gaps in the original physical map based on clones derived directly from amplisomal DNA. For the first gap between B1 and A12, all but a 6-kb HindIII restriction fragment of the BAC clones $762 \mathrm{~S} 8$ and $692 \mathrm{E} 8$ could be accounted for by clones A5, A12, B1, and E8. This $6-\mathrm{kb}$ fragment hybridized to the $1.3-\mathrm{kb}$ vector

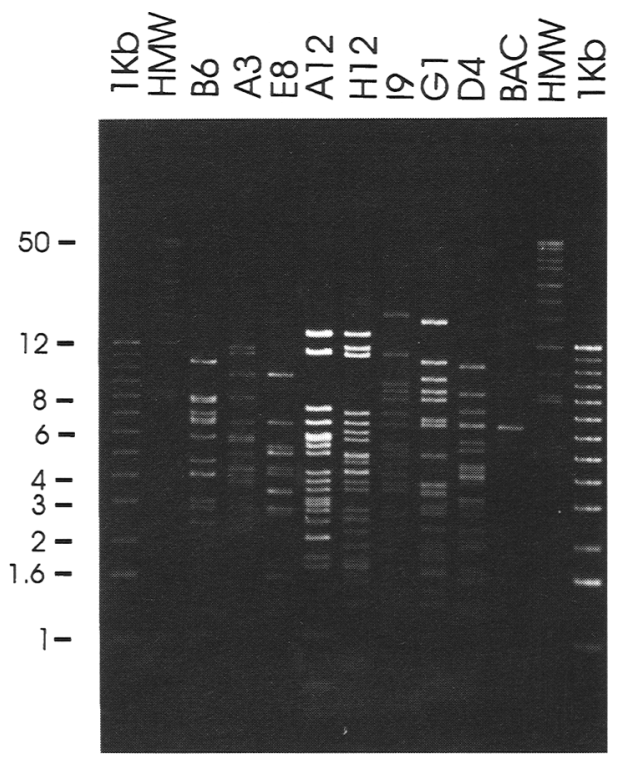

Figure 1 Fingerprinting of amplisome BACs by EcoRI digestion. BAC DNA was prepared by use of Qiagen columns and digested with EcoRI. The gel was run for $20 \mathrm{hr}$ at $14^{\circ} \mathrm{C}$ in a Bio-Rad FIGE-MAPPER with voltage gradients of $9 \mathrm{~V} / \mathrm{cm}$ forward and 6 $\mathrm{V} / \mathrm{cm}$ backward, linear switch time ramping from 0.2 to $1 \mathrm{sec}$ (Birren and Lai 1993). The gel was 1\% LE agarose in $1 \times$ TAE buffer. The names of the BACs are shown on top of the wells, and the size markers were high molecular weight (HMW) and 1-kb ladder from Life Technologies. containing a HindIII fragment of E8, the $1.2-\mathrm{kb}$ vector containing a HindIII fragment of A12, and to the $630-\mathrm{kb}$ amplisomal DNA. These results indicate that this fragment bridges the gap between E8 and A12, and the size of this gap is no more than $3.5 \mathrm{~kb}$. Similarly, for the second gap, all except a $26.5-\mathrm{kb}$ region in clones $611 \mathrm{~A} 8$ and $1014 \mathrm{C} 11$ can be accounted for by clones B6 and D4, which suggests that the size of the gap between $\mathrm{B} 6$ and D4 is no more than $26.5 \mathrm{~kb}$. DNA fragments from the two gaps hybridized to the $630-\mathrm{kb}$ amplisomal DNA, indicating that the sequences are also present in the amplisomes. Yang et al. (1984) and Chen et al. (1984) have reported the structure and organization of the $50-\mathrm{kb}$ chromosomal region surrounding the DHFR gene. No other genomic clones flanking the DHFR region have been reported. We have initiated the cloning of the chromosomal DHFR region corresponding to the amplisomal contig. Preliminary fingerprinting data show an excellent correlation between the amplisomal BACs and their chromosomal counterparts except in the middle of BAC clone 19 (B. Lipes, M. Wang, and E. Lai, in prep.). Thus, the amplisomal BACs can be used for analyzing sequences in this chromosomal region, and we have sequenced clone D8 in collaboration with the Whitehead Genome Center (E. Lai, B. Birren, and T. Hawkins, in prep.).

\section{DISCUSSION}

The physical map of the amplisome is shown in Figure 2. This map integrates all of the hybridization, STS content mapping, fingerprinting, and long-range restriction data. The results from these independent approaches were totally consistent. Every region of the amplisome is covered by at least two BACs, except for a small region between $\mathrm{G} 1$ and $\mathrm{D} 4$. To ensure that the BACbased physical map is a true representation of the amplisome, we have compared the BAC-based physical map with the long-range restriction map reported previously (Esnault et al. 1994). The $\mathrm{BAC}$ clones were digested with infrequentcutting restriction enzymes used in the construction of the long-range map. The position of the restriction sites in the $\mathrm{BAC}$ contigs were then correlated with the long-range map. The restriction enzyme sites shown above the line in Figure 2 represent sites found in both the long-range map and the BAC-based physical map. The restriction sites shown below the line represent sites found in the $\mathrm{BAC}$ clones only and not in the long-range 
WANG EI AL.

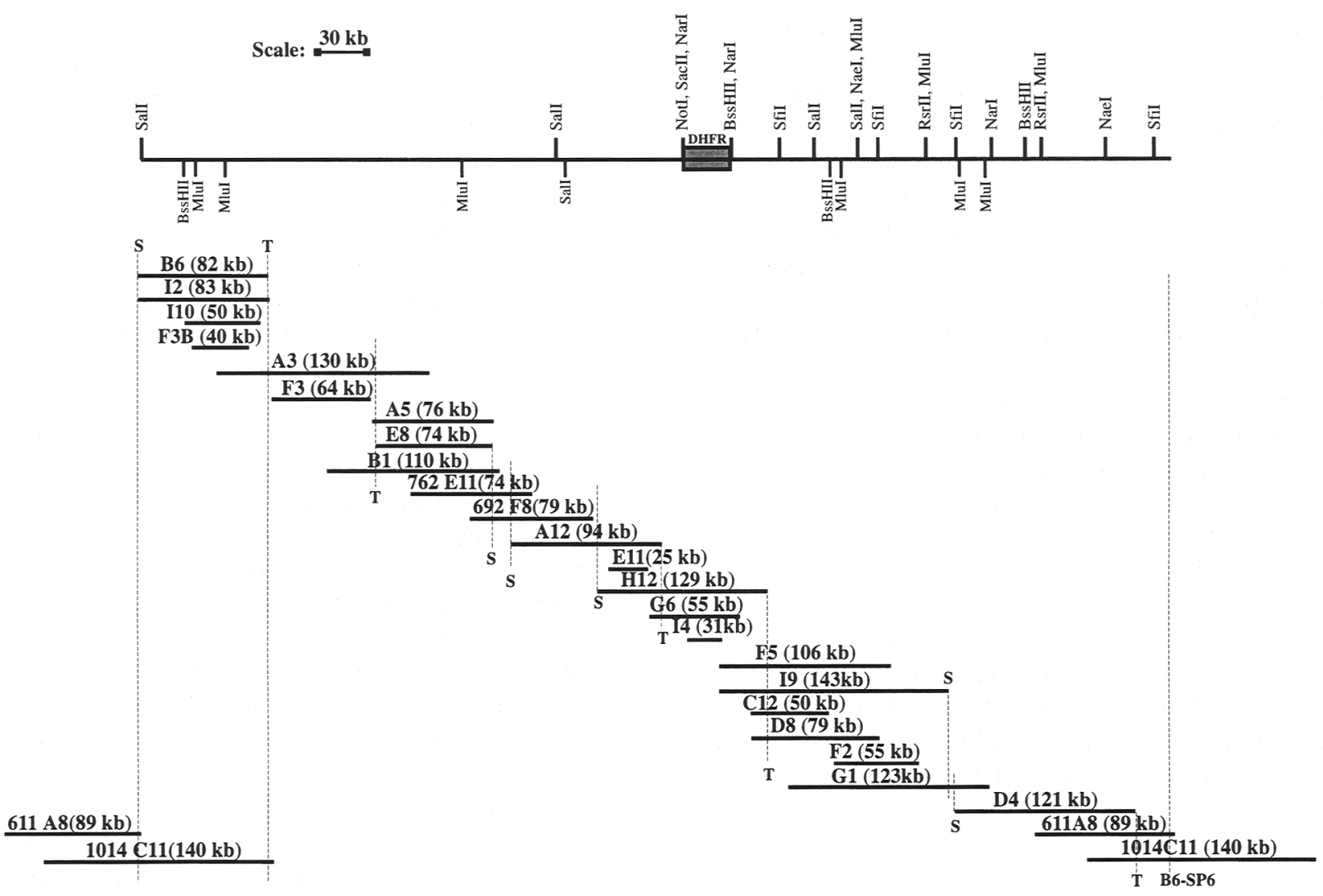

Figure 2 The physical map of the amplisome is represented by a series of overlapping BACs in the middle. The lengths of the BACs are drawn proportionally to their insert sizes. Thus, the amount of overlap between clones can be measured directly from the figure. The positions of the STSS are shown by the vertical lines. STSs generated from the SP6 and the T7 ends are represented as S and T, respectively. Clones 611A8 and 1014C11 are shown twice because of the circular nature of the amplisome. The long-range restriction map of the amplisome is represented by the line at the top. The restriction sites shown above the line are those sites identified by PFGE mapping of amplisomal DNA (Esnault et al. 1994), the sites shown below the line are those cleaved only after cloning of the amplisomal sequences into bacteria, where the cellular methylation pattern would be lost. All sites detected by PFGE were found in the BACs.

map, presumably because of methylation of the sites in vivo. Thus, the BAC-based physical map is consistent with and can be confirmed by the long-range restriction map.

The comprehensive physical mapping approach shown in this report is very efficient. The 630-kb amplisome was mapped completely by use of $\sim 20$ hybridizations, 11 PCR assays for STSs, and three fingerprinting experiments. The approach is also very rapid because both hybridization and STS content experiments can be carried out concurrently. There are advantages and disadvantages associated with each of the mapping procedures used in this report. The advantages of hybridization techniques include the ability to screen massive numbers of clones in parallel without pooling, the ability to perform multiplex probing at relatively low cost, and more importantly, the ability to estimate the extent of overlap from the hybridization signals. The physical map of the amplisome could be deduced after $\sim 10$ hybridizations over 3 weeks at a cost of $<\$ 200$. The major disadvantage of the hybridization as we performed it was the use of radioactivity. Direct sequencing of the insert ends followed by STS-PCR screening is similar to the STSmapping approach used by a number of genome centers in the mapping of the whole human genome or for individual human chromosomes. The cost of STS-mapping, however, is much higher than either hybridization or fingerprinting. The cost of developing the 11 STS sets in this report was $-\$ 1500$ ( $\$ 500$ for sequencing, and $\sim \$ 1000$ for oligonucleotide and enzymes for 
PCR). This explains why we have developed only 11 STSs from the BACs for the confirmation of the hybridization data. The cost of developing STSs from all the BACs would have been $>\$ 7000$, a prohibitive amount for a small molecular biology laboratory. Finally, we used fingerprinting to estimate the amount of overlap among clones. This is the quickest, least expensive, and most reliable method for the estimation of clone overlap and provides excellent confirmation of the physical map created by hybridization and STS content mapping. This application of the technique, however, is markedly different from the technique for which restriction enzyme fingerprinting is used as the primary approach for constructing contigs from anonymous clones. In that case, great care (and a high degree of overlap) is needed to prevent declaration of false links between clones.

Our data demonstrate clearly that the structure of amplisome molecules is homogeneous in 10B3 cells. There is one copy of DHFR gene per amplisome, and no large repetitive structure is detected. This is in sharp contrast with the observed structure and organization of the other cytogenetic anomalies such as DMs, episomes, or homogeneous staining regions that are also associated with amplified genes (Cowell 1982; Carroll et al. 1987; Looney et al. 1988; Ma et al. 1988). Many groups have studied the size of the amplification units and the organization of the amplified genes on DMs, episomes, and HSRs. The structure of the amplified DNA sequences in different loci has been shown to be organized as head-to-tail tandem arrays (Looney et al. 1988; $\mathrm{Ma}$ et al. 1988) or as inverted duplications (Carroll et al. 1987). The structure and organization of the amplified DNA sequences in DMs have also been shown to be highly heterogeneous, even in a single cell or cell line. For example, Nonet et al. (1993) have determined the organization of the extrachromosomal amplicons of the mouse $\mathrm{B}-1 / 50$ cells to be $-250 \mathrm{~kb}$. However, there are many other extrachromosomal elements with different sizes in B-1/50 cells. Other experiments showed that numerous DNA rearrangements can be found in cell lines with amplified DNA and that the amplified structure undergoes complex rearrangements continually (Hahn et al. 1992a). Thus, the case of $10 \mathrm{~B} 3$ cells where a single-size amplisome is found and maintained through hundreds of generations is exceptional. Hahn et al. (1992b) have demonstrated that DMs can be used as megabase cloning vehicles. The ampli- somes might be a more suitable system for this purpose because of their smaller size and stability as extrachromosomal elements, and our ability to transfer large DNA fragments into recipient cells. Thus, cloning of the amplisome into BACs will provide the means to better understand the functional significance of the DNA sequences on the amplisomes and its behavior in vivo and might enable us to construct a mammalian cloning vector.

\section{METHODS}

\section{Construction of the Amplisomal BAC Library}

The amplisomal BAC library was constructed with the second-generation $\mathrm{BAC}$ vector pBeloBAC11, which incorporated the $l a c Z$ gene for color selection of insert-containing clones (Sheng et al. 1995). The amplisomal DNA was enriched from HeLa-Bu25-10B3 cell DNA by digestion of genomic DNA with $\mathrm{NruI}$, followed by separation in a PFG at $2 \mathrm{~V} / \mathrm{cm}, 1800-2700 \mathrm{sec}$ linear switch time ramping for 18 hr. Approximately $90 \%$ of the circular amplisomal DNA are methylated at their $\mathrm{NruI}$ sites and therefore remain uncut (Esnault et al. 1994). These circular molecules are trapped at the wells (Esnault et al. 1994) and can be recovered from the gel by Gelase (Epicentre Technologies, Madison, WI) digestion. About $50 \mathrm{ng}$ of enriched amplisomal DNA was isolated from $15 \mu \mathrm{g}$ of total genomic 10B3 DNA. The amplisomal DNA was then partially digested with Sau $3 \mathrm{~A}$ and ligated to BamHI-digested and dephosphorylated pBeloBAC11 vector (1:10 molar ratio of insert to vector). The ligation mixture was drop-dialyzed against 5 $\mathrm{mM}$ Tris-0.5 mM EDTA $(0.5 \times \mathrm{TE})$ with a $0.025 \mu \mathrm{m}$ filter (Millipore VSMP 02500) for $30 \mathrm{~min}$ before electroporation. Electroporation into DH10B cells (Life Technologies) was performed with $0.2-\mathrm{cm}$ cuvettes at $2.5 \mathrm{kV}, 200 \mathrm{ohms}$ resistance, and $25 \mu \mathrm{F}$ capacitance in the Bio-Rad Gene Pulser electroporator. The BAC clones were plated onto L plates with $12.5 \mu \mathrm{g} / \mathrm{ml}$ of chloramphenicol, $64 \mu \mathrm{g} / \mathrm{ml}$ of X-gal, $32 \mu \mathrm{g} / \mathrm{ml}$ of isopropyl thiogalactopyranoside (IPTG), and incubated for $16-24 \mathrm{hr}$ at $37^{\circ} \mathrm{C}$. About one thousand white clones (i.e., clones that contain inserts) were picked and gridded on nylon membranes (Amersham). Replicate filters were prepared and hybridized with (1) human CotI DNA (Life Technologies, Gaithersberg, MD), (2) human DHFR CDNA, and (3) amplisomal DNA that had been blocked with total placental human DNA. Twenty-one amplisomal BAC clones were identified by this approach. These BAC clones are available from Eric Lai.

\section{Detection of Overlapping BACs by Filter Hybridization}

The Notl-digested amplisomal BAC DNAs were separated in PFGs as described above. After staining with ethidium bromide, DNA inserts were excised, purified by use of a Geneclean II Kit (Bio 101, La Jolla, CA), and radiolabeled with ${ }^{32} \mathrm{P}$ by random hexanucleotide labeling to a specific activity of at least $1 \times 10^{9} \mathrm{cpm} / \mu \mathrm{g}$ of DNA. The replica filters of amplisomal BACs were hybridized under suppres- 


\section{WANG ET AL.}

sive conditions in which the amplisomal BAC insert probes were preannealed with unlabeled total placental human DNA before being added to the hybridization mixture. The labeled probe DNA was mixed with $500 \mu \mathrm{g}$ of total placental human DNA (Sigma Chemical, St. Louis, $\mathrm{MO})$ in $300 \mu \mathrm{l}$ of $1 \times$ SET $(0.6 \mathrm{M} \mathrm{NaCl}, 0.03 \mathrm{M}$ EDTA, $0.2 \mathrm{M}$ Tris-Cl at $\mathrm{pH} 8.0,2 \% \mathrm{SDS}, 0.1 \%$ sodium pyrophosphate), boiled for $10 \mathrm{~min}$, and preannealed at $68^{\circ} \mathrm{C}$ for $2.5 \mathrm{hr}$. The preannealed probe was then added to the filters that had been prehybridized in $1 \times \mathrm{SET}$ at $68^{\circ} \mathrm{C}$ for at least $2 \mathrm{hr}$. After overnight hybridization, the filters were washed for 5 min at room temperature in $2 \times$ SSC and $0.2 \%$ SDS, for 15 min at $68^{\circ} \mathrm{C}$ in $2 \times \mathrm{SSC}$ and $0.2 \%$ SDS, and for $15 \mathrm{~min}$ at $68^{\circ} \mathrm{C}$ in $0.1 \times$ SSC and $0.2 \%$ SDS.

\section{STS Content Mapping of the Amplisomal BACs by PCR}

PCR conditions were $10 \mathrm{ng}$ of BAC DNA or $1 \mu \mathrm{g}$ of total human DNA as target DNA, $1 \mu \mathrm{M}$ of each primer, $0.2 \mathrm{~mm}$ dNTP, $10 \mathrm{~mm}$ Tris at $\mathrm{pH} 8.0,50 \mathrm{mM} \mathrm{KCl}, 1.5 \mathrm{~mm} \mathrm{MgCl}_{2}$, $0.1 \%$ Triton X-100, and 0.6 units of AmpliTaq polymerase (Perkin-Elmer) in a final volume of $100 \mu \mathrm{l}$. The reactions were performed with a hot-start protocol. Amplifications were carried out in a Perkin-Elmer 480 Thermal Cycler with a denaturation step of $94^{\circ} \mathrm{C}$ for $2 \mathrm{~min}$, an annealing step of $55^{\circ} \mathrm{C}$ for $2 \mathrm{~min}$, and an extension step of $72^{\circ} \mathrm{C}$ for 2 min for 30 cycles. A final elongation step of $72^{\circ} \mathrm{C}$ for 10 min was used after the last cycle. Products from the PCR reactions were separated in $1 \%$ SeaKem LE agarose gel and detected by ethidium bromide staining.

\section{Fingerprinting of $\mathrm{BAC}$ clones}

BAC DNAs were prepared by use of Qiagen columns and digested with the restriction enzymes. EcoRI, BamHI, HindIII, NotI, SalI, MluI, and SfiI (New England Biolabs, Beverly, MA). All gels were stained in ethidium bromide and photographed. Gel pictures were scanned by a GS- $670 \mathrm{im}-$ age densitometer, and the fragments were sized by the Molecular Analyst TM/PC image analysis software (BioRad Laboratories, Richmond, CA).

\section{ACKNOWLEDGMENTS}

We thank Dr. B. Birren for the critical reading of the manuscript, and the laboratory of Dr. M. Simon for providing the pBeloBAC11 vector and procedures for the BAC cloning. This work was supported by National Institutes of Health grant (R29-GM45943) to E.L. The sequence data described in this paper have been submitted to the dbSTS data library under accession nos. 34709-34719.

\section{REFERENCES}

Altshul, S.F., W. Gish, W. Miller, E.W. Myers, and D.J. Lipman. 1990. Basic local alignment search tool. J. Mol. Biol. 215: 403-410.

Ashworth, L.K., M. Alegria-Hartman, M. Burgin, L. Devlin, A.V. Carrano, and M.A. Batzer. 1995a. Assembly of high-resolution bacterial artificial chromosome, P1-dervied artificial chromosome, and cosmid contigs. Anal. Biochem. 224: 564-571.

Ashworth, L.K., M.A. Batzer, B. Brandriff, E. Branscomb, P. de Jong, E. Garcia, J.A. Garnes, L.A. Gordon, J.E. Lamerdin, G. Lennon, et al. 1995b. An integrated metric physical map of human chromosome 19. Nature Genet. 11: $422-427$.

Birren, B. and E. Lai. 1993. Pulsed field gel electrophoresis. A practical guide, 1st ed. Academic Press. Orlando, FL.

Branscomb, E., T. Slezak, R. Pae, D. Gales, A.V. Carrano, and M. Waterman. 1990. Optimizing restriction fragment fingerprinting methods for ordering large genomic libraries. Genomics 8: 351-366.

Burke, D.T., G.F. Carle, and M.V. Olson. 1987. Cloning of large segments of exogenous DNA into yeast using artificial-chromosome vectors. Science 236: 806-812.

Carroll, S., P. Gaudray, M.L. DeRose, J.F. Emery, J.L. Meinkoth, E. Nakkim, M. Subler, D.D. Von Hoff, and G.M. Wahl. 1987. Characterization of an episome produced in hamster cells that amplify a transfected CAD gene at high frequency: Functional evidence for a mammalian replication origin. Mol. Cell. Biol.

7: $1740-1750$

Chen, M-J., T. Shimada, A.D. Moulton, A. Cline, R.K. Humphries, J. Maizel, and A.W. Nienhuis. 1984. The functional human dihydrofolate reductase gene. J. Biol. Chem. 259: 3933-3943.

Cowell, J.K. 1982. Double minutes and homogeneously staining regions: Gene amplification in mammalian cells. Annu. Rev. Genet. 16: 21-59.

Esnault, C., H. Lee, and E. Lai. 1994. Structure and organization of a stable extrachromosomal element in human cells. Gene 144: 205-211.

Hahn, P.J., B. Nevaldine, and J.A. Longo. 1992a. Molecular structure and evolution of double-minute chromosomes in methotrexate-resistant cultured mouse cells. Mol. Cell. Biol. 12: 2911-2918.

Hahn, P.J., L. Giddings, J. Longo, M.J. Lane, J. Scalzi, and J. Hozier. 1992b. Double-minute chromosomes as megabase cloning vehicles. Genet. Anal. Tech. Appl. 9: $17-25$.

Hosoda, F., S. Nishimura, H. Uchida, and M. Ohki. 1990. An $\mathrm{F}$ factor based cloning system for large DNA fragments. Nucleic. Acids Res. 18: 3863-3869.

Ioannou, P.A., C.T. Amemiya, J. Grarnes, P.M. Kroisel, H. Shizuya, C. Chen, M.A. Batzer, and P.J. De Jong. 1994. A new bacteriophage P1-derived vector for the propagation of large DNA fragments. Nature Genet. 6: 84-89.

Kim, U-J., B.W. Birren, T. Slepak, V. Mancino, C. Boysen, H.-L. Kang, M.I. Simon, and H. Shizuya. 1996. 


\section{GENOMIC CLONING IN BACS}

Construction and characterization of a human bacterial artificial chromosome library. Genomics (in press).

Lamerdin, J.E. and A.V. Carrano. 1993. Automated fluorescence-based restriction fragment analysis. BioTechniques 15: 294-302.

Looney, J.E., C. Ma, T.-H. Leu, W.F. Flintoff, W.B. Troutman, and J.L. Hamlin. 1988. The dihydrofolate reductase amplicons in different methotrexate-resistant Chinese hamster cell lines share at least a 273-kilobase core sequence, but the amplicons in some cell lines are much larger and are remarkably uniform in structure. Mol. Cell. Biol. 8: 5268-5279.

Ma, C., J.E. Looney, T.-H. Leu, and J.L. Hamlin. 1988. Organization and genesis of dihydrofolate reductase amplicons in the genome of a methotrexate-resistant chinese hamster ovary cell line. Mol. Cell. Biol. 8: $2316-2327$.

Masters, J., B. Keeley, H. Gay, and G. Attardi. 1982. Variable content of double minute chromosomes is not correlated with degree of phenotype instability in methotrexate-resistant human cell lines. Mol. Cell. Biol. 2: 498-507.

Maurer, B., E. Lai, B.A. Hamkalo, L. Hood, and G. Attardi. 1987. Novel submicroscopic extrachromosomal elements containing amplified DHFR genes in human cell lines. Nature 327: 434-437.

Nonet, G.H., S.M. Carroll, M.L. DeRose, and G.M. Wahl. 1993. Molecular dissection of an extrachromosomal amplicon reveals a circular structure consisting of an imperfect inverted duplication. Genomics 15: 543-558.

O'Conner, M., M. Peifer, and W. Bender. 1989. Construction of large DNA segments in Escherichia coli. Science 244: 1307-1312.

Pauletti, G., E. Lai, and G. Attardi. 1990. Early appearance and long-term persistance of the submicroscopic extrachromosomal elements (amplisomes) containing the amplified DHFR genes in human cell lines. Proc. Natl. Acad. Sci. 87: 2955-2959.

Sheng, Y., V. Mancino, and B. Birren. 1995. Transformation of E. coli with large DNA molecules by electroporation. Nucleic Acids Res. 23: 1990-1996.

Shizuya, H., B. Birren, U.J. Kim, V. Mancino, T. Slepak, Y. Tachiri, and M. Simon. 1992. Cloning and stable maintenance of 300-kilobase-pair fragments of human DNA in Escherichia coli using F-facter-based vector. Proc. Natl. Acad. Sci. 89: 8794-8797.

Sternberg, N. 1990. Bacteriophage P1 cloning system for the isolation, amplification, and recovery of DNA fragments as large as 100 kilobase pairs. Proc. Natl. Acad. Sci. 87: 103-107.

Wang, M. and E. Lai. 1995. Pulsed field separation of large supercoiled and open-circular DNAs and its application to bacterial artificial chromosome cloning. Electrophoresis 16: 1-7.

Wang, M., X.-N. Chen, S. Shouse, J. Manson, Q.-Z. Wu, R. Li, J. Wrestler, D. Noya, Z.-G. Sun, J. Korenberg, and E. Lai. 1994. Construction and characterization of a human chromosome 2 specific BAC library. Genomics 24: $527-534$.

Yang, J.K., J.N. Masters, and G. Attardi. 1984. Human dihydrofolate reductase gene organization. J. Mol. Biol. 176: $169-187$.

Received March 7, 1996; accepted in revised form May 24, 1996. 


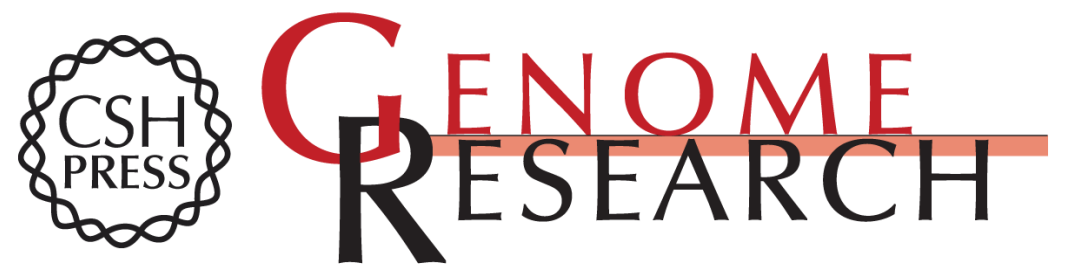

\section{Bacterial artificial chromosome cloning and mapping of a $630-\mathrm{kb}$ human extrachromosomal structure.}

M Wang, S Shouse, B Lipes, et al.

Genome Res. 1996 6: 612-619

Access the most recent version at doi:10.1101/gr.6.7.612

References This article cites 27 articles, 11 of which can be accessed free at:

http://genome.cshlp.org/content/6/7/612.full.html\#ref-list-1

\section{License}

Email Alerting Receive free email alerts when new articles cite this article - sign up in the box at the Service top right corner of the article or click here.

\section{Affordable, Accurate Sequencing.}

To subscribe to Genome Research go to:

https://genome.cshlp.org/subscriptions 